\title{
FAMILY BUSINESS CONTINUANCE: A REVIEW FOR FUTURE RESEARCH
}

\author{
Annisa Ramadanti*)1, Nyayu Lathifah Tirdasari*), Wawan Dhewanto**) \\ ${ }^{*}$ School of Business, IPB University \\ Jl. Pajajaran, Bogor 16151, Indonesia \\ ${ }^{* *}$ School of Business and Management, Institut Teknologi Bandung \\ Jalan Ganesha No.10, Bandung, West Java 40132, Indonesia
}

\begin{abstract}
The process of changing leaders from the previous leaders to the recent leaders is a critical moment in family business continuance. The complex issue of succession needs an indepth understanding of researches. This paper's objective was to review several works of literature with regards to succession in the family business. Moreover, this study discovered future research potentials concerning family business succession. This study reviewed, summarized, and combined the past and extant works of literature. China, Malaysia, Pakistan, Slovenia, and Tunisia emerged as the locus of study. This study performed a review using keywords of family business and succession to look for a comprehensive database. This study found that each country has a different culture in doing their family business succession. The most influential factor was the belief of the predecessor. For instance, the Chinese families were following Confucian rules, the Pakistani and Malaysian families were following Islamic laws, and the predecessors influenced the Tunisian families in involving their children in their family business. Meanwhile, the first generation still dominated the family business in Slovenia without any succession plan. The results show opportunities for a new research agenda. First, the comparison of family business succession between various ethnic groups. Second, the reason(s) for a family business to not set its succession plan.
\end{abstract}

Keywords: business continuance, family business research, literature review, succession

Abstrak: Proses perubahan pemimpin dari pemimpin sebelumnya ke pemimpin terkini merupakan momen penting dalam kelangsungan bisnis keluarga. Permasalahan suksesi yang kompleks memerlukan pemahaman mendalam dari penelitian. Tujuan penelitian ini adalah untuk mengkaji pustaka terkait suksesi dalam bisnis keluarga. Selain itu, penelitian ini menemukan potensi penelitian selanjutnya terkait suksesi bisnis keluarga. Penelitian ini mengkaji, merangkum, dan mengombinasikan pustaka lampau yang ada. Cina, Malaysia, Pakistan, Slovenia, dan Tunisia menjadi lokus penelitian ini. Penelitian ini melakukan pengkajian menggunakan kata kunci bisnis keluarga dan suksesi untuk mencari basis data yang komprehensif. Penelitian ini menemukan bahwa setiap negara memiliki budaya yang berbeda dalam melakukan suksesi bisnis keluarga. Faktor yang paling berpengaruh adalah kepercayaan para pendahulu. Sebagai contoh, keluarga Cina yang mengikuti aturan/kebiasaan Konfusianisme, keluarga Pakistan dan Malaysia yang menggunakan hukum Islam, dan para penduhulu yang memengaruhi keluarga Tunisia dalam melibatkan anak-anak mereka dalam bisnis keluarga mereka. Sementara itu, generasi pertama masih mendominasi bisnis keluarga di Slovenia, tanpa adanya rencana suksesi. Hasil penelitian ini menunjukkan peluanf untuk agenda penelitian baru. Pertama, perbandingan suksesi bisnis keluarga antar-kelompok etnis yang berbeda. Kedua, alasan-alasan bisnis keluarga untuk tidak/ belum menetapkan rencana suksesi.

Kata kunci: kelangsungan bisnis, penelitian bisnis keluarga, tinjauan pustaka, suksesi

\footnotetext{
${ }^{1}$ Corresponding author:

Email: aramadanti@apps.ipb.ac.id
} 


\section{INTRODUCTION}

A business owned, managed, and run by a family is the leading characteristic of enterprise worldwide. It is well known for its joint system complexity, conflicts of concern, and discontinuity (Bowman-Upton, 1988). This article illustrates a family business as a profit organization owned and the strategic employment occupied by family members (Astrachan et al. 2002; Distelberg, 2009; Litz, 1995; Martos, 2007). Succession is a crucial matter which mostly family business needs to care. Several works approved the issue of succession of literature. Succession had been an unfortunate thing in the family business cycle (Ibrahim et al. 2006). In addition, proceeding with the business over succession is a challenging thing to do (Walter, 2009). Financial issues have been the reason for many family business succession failures (Koropp et al. 2013). Even though canvasing family business is complicated due to the shortcoming work of literature and their tacit nature, research about family business issues exists in large amounts. Studies in succession areas have significantly elevated not only in quality but also in quantity.

Moreover, it has lied as from the past. For instance, research related to the management succession in a family business which Justin G. Longenecker conducts and John E. Schoen first published in 1978. Family business existence breaks the contemporary organization principle that is separating ownership from management (Morris, 1999). This unique characteristic caused a disparity between a family business and other kinds of enterprise forms. The top difference is how they deal with the succession process. The family business cannot sidestep succession. It causes a preparation that the family business needs (Tirdasari and Dhewanto, 2012). Even though there are various modes to prepare the business continuance, as handing over the company to other executives or selecting non-family member's management as an exit route, this paper was written to focus on how to handle its succession. This research investigated, recapped, and integrated past and present works of journal articles. The investigation started using keywords family business and succession planning to look for a comprehensive database.

This paper aims to review several pieces of literature regarding succession in the family business and discover future research about the succession issue. This study is deemed necessary as succession is pivotal to care in the family business. A review of succession in several different countries would enrich the understanding of this topic. This study would contribute to complete a research agenda in family business succession, provide a reference for future research and knowledge for the readers, and convey recommended topics for the research agenda. The general hypothesis of this study was that there are different views concerning family business succession, and countries have differences in family business succession culture due to specific influential factor(s). This article begins by emphasizing the issue related to family business succession and then followed by the theoretical constructs. In this section, we reviewed few theories which are primary in this area. Then followed by the main section, this section consists of discussion in choosing a potential successor, predecessor outlook, and a succession which happens in some selected locus then finished with a suggestion for future research. This article concerned the succession process. The last section concluded this paper and described the contribution of this research.

\section{METHODS}

A literature review method was employed in this study. The filters applied to the searching process were academic journals, full text, peer-reviewed, last ten years, and English. The filter itself is a feature that is already available on the online database, making the search process more manageable. However, the search phase ended up with a large volume of references that may be relevant or irrelevant to the criteria. It revealed about 400 results. So that this study did the screening, each work of literature' title and abstract are scanned, respectively. The study selected the paper which fitted the criteria and collected it to an online document folder. This study selected articles published from January 2011 until December 2021 and included them in the analysis. In addition, it comes from various sources available on ProQuest, an online database employed in this study. The keywords for searching used in this study were family business, Indonesia, and succession. The word "Indonesia" was used as a keyword only to confirm that the number of the relevant literature concerning Indonesia is limited. Around 40 articles were recruited using the screening method and referred. This section also reviewed several common and popular theoretical concepts that are usually used in research on family business subjects as follows. 


\section{The Agency Theory}

The agency theory is one of the expected theoretical concepts used by family business research to investigate issues on an organization's financial performance, ownership, and management structures (Westhead and Howorth, 2006). This theory is used to explain connections between non-family managers and the enterprise (Chua et al. 2003). It discovered facts, such as the nonfamily managers did not show enough interest in the business as the family member managers themselves.

\section{The Evolutionary Theory}

In several pieces of research, the evolutionary theory was used to plot particular aspects of family business succession into a complete framework (Kansikas and Kuhmonen, 2008). Some principal significances of succession in terms of economic influences were studied, not only the positive impact but also the negative one. This theory was used to provide a principal empirical finding of its effect on a family business achievement. So, the successor point of view may be the base for family business continuance. It also offered a composition for family business continuance and transformation that happen more than many years. It gave ways to find out family business continuance and aspects that affected successions in the family business. This method also generated points in the education context.

\section{The Grounded Theory}

The grounded theory was used to develop a theory based on gathered and analyzed data (Glaser, 1998; Myers, 2009; Strauss and Corbin, 1990). Moreover, it was utilized to analyze life-story findings on business experiences to understand the difficulties of family business succession. This approach is the most appropriate way to investigate the succession process (Solomon et al. 2011). It kept the researcher on track with the data and provided possibilities to examine the problematic psychological phenomena. This theory assisted the researcher in seeing data through their point of view. The critical value of this theory is that it develops an inductive theory from existing data to illustrate a social phenomenon. After all, this theory explained the observed event scientifically.

\section{The Resource-Based View Theory}

The resource-based view theory proposed that the resources of an organization were valuable, unique, and genuine. Intangible resources might be the basis for a business continuance (Barney, 1991). Characteristics such as valuable, unique dan genuine made intangible resources are challenging to duplicate. Intangible property, like culture, influenced the succession moment. This theory was used to create a model using a family's culture as a competitive advantage in a family business (Campbell et al. 2007). This method was also employed to examine the competency of the potential continuer to acquire the current leader knowledge and capabilities to organize the family business accomplishment (CabreraSuárez et al. 2001) successfully. The result revealed a concept related to the figure and learning process under the business, which underlies the improvement of the business's competitive advantage. It involved sophisticated, intangible, and viable properties in looking at a business. To conclude, the resource-based view theory was an appropriate approach for studying the family business (Habbershon and Williams, 1999).

\section{The Planned Behavior Theory}

In general, the planned behavior theory clarified and looked at a diversity of human behaviors across different settings (Ajzen and Fishbein, 1980; Ajzen, 1999). Some researchers have successfully utilized the theory to examine succession decisions (Sharma et al. 2003). The planned behavior theory was employed to investigate different business subjects since the theory was suitable (Mjebri and Affes, 2012). This theory was also used to define better motives of Tunisian predecessors to fulfill succession. Furthermore, the theory predicted a behavior by understanding individual motives (Ajzen and Fishbein, 1980). Planned behavior theory enabled behavior in the succession process that occurred, relying on specific individuals. In addition, the intention is created by the manner, which in turn resulted in the behavior. This method was utilized to hypothesize the impact of the predecessor's motive to defend the three activities, namely the family's enterprise, the family's loyalty to the company, and the eagerness of the potential successor to lead the business (Sharma et al. 2003). 


\section{RESULTS}

\section{Daughter as a Successor}

Generally, females neglected to become the next leader because their family business works were not valued. However, women entrepreneurs are influenced by the consequences of economic involvement and entrepreneurship perceived potentials (Brush et al. 2017). Because of many variables that convinced her to work toward the company, female inequality remains invisible (Wang, 2010). Some founders assumed that their daughters have to try harder than sons to lead the company (Vera and Dean, 2005). On the contrary, the current leader chose to sell the organization rather than allow their daughter to lead (Stavrou, 1999).

Some works of literature say otherwise. Females may be more valuable as inheritors (Dumas, 1992; Salganicoff, 1990). So they should not be ignored as the prospective successor. They are essential for a family business (Heinonen and Stenholm , 2011). They were ignoring the potential of females delivered suboptimal options of successors. The female's succession is seen as a complementarity (Dumas, 1992). Generally, daughter succession is related to four types of issues: a) the impact of culture, b) gender issues, c) family role, and d) preparing and tutoring (Qin and Wang, 2012). When females run a company, some challenges are encountered. They may be getting into a discomfort zone for a woman. They might face gender discrimination (Mischel and Iannarelli, 2011).

\section{Predecessor Vista on Succession}

Not all predecessors consider retirement and succession planning, only slightly who seriously did this. This plan can endanger the family business continuance itself. It was estimated that not as much as one-third of the family business continuance is proceed to the next generation, and fewer than fifteen percentages keep on to the third generation (Bowman-Upton, 1988). These facts may be due to the nonexistence of succession planning, the objection of predecessors to discharge the business, and many other reasons.

The low desire of the current leader to leave the business resulted in bad influences on the succession. Some factors were causing this propensity, such as fear of losing power. Due to psychological reasons, many predecessors ignored intend for retirement (Francis,
1993). On the other side, if predecessors had intended to perform a succession, there are three essential things that predecessors need to master (Bowman-Upton, 1988): a well-planned succession, stable asset values, and a determination of managerial control.

The predecessors must highlight that they need to believe their offspring's intentions in fully continuing the family business. To ensure the offspring's intention, predecessors need to ask them (Stavrou, 1999). Oldsters should provide options to their youngsters if they are willing to continue the business and have capabilities. Effective communication between predecessors and family members is needed through this process. Predecessor can become the source of knowledge and insight for the successor to pass on the entrepreneurial intents (Hopp et al. 2019).

\section{Succession in Several Countries}

This study conducted a literature review in a specific locus. These works of literature discoveries flashed on some distinctive cultures of succession, as discussed below.

China

Confucian ideology provided a critical role in succession in China. Through a multilevel analysis, there are five issues adopted in Yan and Sorensen (2006) based on Confucian ideology. One is family as the fundamental unit of a civilization, two is a parentchild dyad, three is family relations, four is community relationships, and five is the legacy of the family assets. A case study mentioned that Confucian ideology brings the Chinese enterprises to specify the role and boost the successor to join the family business (Qin and Wang 2012). In addition, usually, the Chinese wanted to keep the business under the family. In general, the Chinese predecessor plays three responsibilities: tutors for the daughter, channel of the two-generation, and encouragement for the chosen successor. Since culture is challenging to revolutionize, it may merely forecast that family business will still be scattered in China and persist for a sustained time, as in Western.

Chinese family business familiarized with the term guanxi. In Chinese, guanxi is a critical property for entrepreneurs because it provided a diversity of resources. Guanxi is considered a unique feature in Chinese social capital (Dou and Li, 2012). They defined 
it as a familiar, particularistic individual relationship between two persons surrounded by an unspoken psychological bond to obey the social standard. An exploratory case study exemplified social standards (Amran and Che, 2010): preserving a long-range bond, mutual commitment, faithfulness, and obligation. Female leadership in China is started popping up. The emerge caused by the institutional change which brings the part of daughters over the family system.

\section{Malaysia}

Succession is quite common within the family business in Malaysia. Through balanced data analysis, Malaysian family businesses created plans to continue their legacy (Amran and Che,2010). Moreover, junior managers within the company behave well than senior managers. The junior managers are more enterprising and risktaking than the senior ones in leading the company. In Malaysia, women entrepreneurs face several lacks, such as spousal support, confidence, networking, etc. Most of the female leads the micro-size business.

\section{Pakistan}

The generality of family businesses in Pakistan faced succession challenges. Most of the employments in Pakistan came from the company form of the family business. Therefore, family business development is necessary for society (Afghan and Wiqar, 2007). Pakistani cultures are illustrated as solidarity, solitary, courageous, and Sunni Muslims. During the succession process, as the Muslim devout, Pakistani family business obeys their religion. The boundary theory explained that religion fosters specific achievement because of the ability to incorporate faith and entrepreneurship (Smith et al. 2019). The participation of women in employment is increasing even though it becomes difficult because of the patriarchal societies.

\section{Slovenia}

Succession preferred no within the Slovenian. This dislike occurred because the first generation dominated most Slovenian family businesses, so they (predecessor) do not have any succession experience. However, according to Duh et al. (2009), many family businesses will encounter the succession issue in Slovenia. The study conducted the t-test and $\mathrm{x} 2$-test to assess the family businesses. Researches about family business succession problems in transition countries, like Slovenia, are rare. It is because of the outlawed during the socialist economy era. In Slovenia, males have a heterogeneous role in the working world, and it strongly affects their access to the social.

\section{Tunisia}

The family business is dominant in Tunisia. However, there is no statistical information existing about this type of enterprise (Mjebri and Affes, 2012). The motive of the current Tunisian leader to continue the legacy sets their objective of succession. Furthermore, the arrangement is a form of a long-range move. These moves were primarily linked to education. This result led to founders play an essential part in the growth of the entrepreneurial mindset among their offspring. For instance, parents prefer to ask the kids to help within the company rather than send them to formal school. In Tunisia, the gender rate plays a high role in economic growth, includes female contribution.

Many works of literature have shown the process of succession in the family business. This study investigated, recapped, and integrated past and present literature on family business and succession. It covers prevailing theories, issues, and discussions to offer a preferable conception related to family business succession research and broadly illustrates this subject. Common theoretical concepts employed in succession research are the agency theory, the evolutionary theory, the grounded theory, the resource-based view theory, and the planned behavior theory. The most common theory is the agency theory. This theory provides a unique point of view that aligns with the family business's unique nature and presents an empirically legitimate perspective. This study finds some essential factors to construct the process of succession in the family business. The factors are family system, commitment, communication skill, and predecessor or parents role. The lesson that can be drawn from this study is that it is crucial to journalize the succession process. However, some processes run successfully without a written plan. Nevertheless, it is still important to document every step passed to be an example for the next generation and sustain the business.

Somelimitations emerged to offerroom fordevelopment. First, this study employs a qualitative method. Although qualitative research on family business succession still 
needs to be developed from various contexts, it would be good to conduct research that utilizes a quantitative method. Second, the results cannot be generalized for the business in other locations. This article suggests future research first, the extent of founder entanglement after releasing the business to the next generation. Second, to oppose the succession moment by variant ethnicity or culture in Asia. Third, factors that give an impact to a practical and handy process. Fourth is the impact of formal business or management school or informal courses, such as internships, for a successor before joining the company. Last, the reason for a family business does not set its succession planning.

\section{Managerial Implications}

Thisstudy hasmanagerialimplications forunderstanding how the succession process is conducted and influenced in family business. Further research should focus on determining the success factors which influenced the process of succession. Another important practical implication is that the family business should enrich themselves with knowledge of succession so that they can realize how critical this process is for business sustainability. Tracing every process that is carried out or passed for the succession process should be a priority for the current owner.

\section{CONCLUSIONS AND RECOMMENDATIONS}

\section{Conclusions}

Countries differ in viewing daughters as family business successors. Some countries disregard daughters to be successors. Conversely, there are countries that value daughters as prospective successors. Likewise, the predecessors also have differences in viewing succession. There are only some predecessors who plan succession seriously. Regarding the family business succession in China, Malaysia, Pakistan, Slovenia, and Tunisia, each country has different succession culture. The most noticeable factor influencing the family business succession in those countries was the predecessor's belief, such as in China, Malaysia, Pakistan, and Tunisia. However, the succession culture in Slovenia was not prevalent due to the domination of the first generation.

\section{Recommendations}

This study reveals and recommends two potential future research topics. First, future researches could compare family business succession practices between various ethnic groups. Second, future researches could analyze the reason(s) why family businesses have not set their succession plan.

\section{REFERENCES}

Afghan, Wiqar T. 2007. Succession in family businesses of Pakistan: Kinship culture and Islamic inheritance law. CMER Working Paper Series.

Ajzen I, Fishbein M. 1980. Understanding Attitudes and Predicting Social Behavior. New Jersey: Prentice-Hall.

Ajzen I. 1991. The theory of planned behavior. Organizational Behavior and Human Decision Processes 50:179-211. https://doi. org/10.1016/0749-5978(91)90020-T.

Amran N, Che AA. 2010. Family succession and firm performance among Malaysian companies. International Journal of Business and Social Science 1(2):193-203. https://doi.org/10.17576/ ajag-2011-2-6538.

Astrachan JH, Klein SB, Smyrnios KX. 2002. The F-PEC scale of family influence: A proposal for solving the family business definition problem. Family Business Review 15(1):45-58. https:// doi.org/10.1111/j.1741-6248.2002.00045.x.

Barney J. 1991. Firm resources and sustained competitive advantage.JournalofManagement 17(1):99-120. https://doi.org/10.1177/014920639101700108.

Bowman-Upton N. 1988. Family business succession. Baylor Business Review 6(2):26-30.

Brush $C$ et al. 2017. The influence of human capital factors and context on women's entrepreneurship: Which matters more?. Journal of Business Venturing Insights 8:105-113.https://doi. org/10.1016/j.jbvi.2017.08.001.

Cabrera-Suárez K, De Saá-Pérez P, Garcia-Almeida D. 2001. The succession process from a resourceand knowledge-based view of the family firm. Family Business Review 14(1):37-46.https://doi. org/10.1111/j.1741-6248.2001.00037.x.

Campbell ND, Heriot KH, Welsh DHB. 2007. The black box: Unraveling family business succession. New England Journal of Entrepreneurship 10(2):9-14.https://doi.org/10.1108/NEJE-10-02- 
2007-B001.

Chua JH, Chrisman JJ, Sharma P. 2003. Succession and nonsuccession concerns of family firms and agency relationship with nonfamily managers. Family Business Review 16(2):89-107.https:// doi.org/10.1111/j.1741-6248.2003.00089.x.

Distelberg B. 2009. Updating systems consepts in family businesses: A focus on values, resource flows, and adaptability. Family Business Review 22(1):6581.https://doi.org/10.1177/0894486508329115.

Dou J, Li S. 2012. The succession process in Chinese family firms: A Guanxi perspective. Asia Pacific Journal of Management 30:893-917.https://doi. org/10.1007/s10490-012-9287-7.

Duh M, Tominc P, Rebernik M. 2009. Growth ambitions and succession solutions in family businesses. Journal of Small Business and Enterprise Development 16(2):256-269.https:// doi.org/10.1108/14626000910956047.

Dumas C. 1992. Integrating the daughter into family business management. Entrepreneurship Theory and Practice 16(4):41-56.https://doi. org/10.1177/104225879201600403.

Francis BC. 1993. Family business succession planning. Journal of Accountancy 176(2):49.

Glaser BG. 1998. Doing grounded theory: Issues and discussion. Recherche 67:2.

Habbershon TG, Williams ML. 1999. A resource-based framework for assessing the strategic advantages of family firms. Family Business Review 12(1):1-25.https://doi.org/10.1111/j.17416248.1999.00001.x.

Heinonen J, Stenholm P. 2011. The contribution of women in family business. International Journal of Entrepreneurship and Innovation Management 13(1):62-79. https://doi. org/10.1504/IJEIM.2011.038448.

Hopp C, Minarikova D, Speil A. 2019. A chip off the old block? How parent-child interactions affect the intergenerational transmission of entrepreneurial intentions. Journal of Business Venturing Insights 11:130.https://doi.org/10.1016/j.jbvi.2019. e00130.

Ibrahim AB, Soufani K, Poutziouris P, Lam J. 2004. Qualities of an effective successor: The role of education and training. Education + Training 46(8/9):474-480.https://doi. org/10.1108/00400910410569597.

Kansikas J, Kuhmonen T. 2008. Family business succession: Evolutionary economics approach. Journal of Enterprising Culture 16(3):279-298.
https://doi.org/10.1142/S0218495808000156.

Koropp C, Grichnik D, Gygax AF. 2013. Succession financing in family firms. Small Business Economics 41(2):315-334. https://doi. org/10.1007/s11187-012-9442-z.

Litz RA. 1995. The family business: Toward definitional clarity. Family Business Review 8(2):71-81.https://doi.org/10.1111/j.17416248.1995.00071.x.

Martos MCV. 2007. What is a family business? A discussion of an integrative and operational definition. International Journal of Entrepreneurship and Small Business 4(4):473-488.https://doi.org/10.1504/ IJESB.2007.013692.

Mischel L, Iannarelli C. 2011. Understanding a fatherdaughter succession case: Applying the $5+5+5$ Bernelli model. American Journal of Economics and Business Administration 3(2):270-276. https://doi.org/10.3844/ajebasp.2011.265.271.

Mjebri KM, Affes H. 2012. Determinants of intention and succession planning in Tunisian family business. International Journal of Business and Social Science 3(12):118-133.

Morris MH, Ne D, Williams RW. 1999. Factors influencing family business succession. International Journal of Entrepreneurial Behaviour \& Research 2(3):68-81.https://doi. org/10.1108/13552559610153261.

Myers MD. 2009. Qualitative Research in Business and Maanagement. New York: SAGE Publications.

Qin Z, Wang Q. 2012. Father-daughter succession in China: The conceptual framework and a case study. The Business Review Cambridge 20:6876.

Salganicoff M. 1990. Women in family businesses: challenges and opportunities. Family Business Review 3(2):125-137.https://doi.org/10.1111/ j.1741-6248.1990.00125.x.

Sharma P, Chrisman JJ, Chua JH. 2003. Succession planning as planned behavior: Some empirical results. Family Business Review 16(1):1-15.https://doi.org/10.1111/j.17416248.2003.00001.x.

Smith BR, Conger MJ, McMullen JS, Neubert MJ. 2019. Why believe? The promise of research on the role of religion in entrepreneurial action. Journal of Business Venturing Insights 11.https:// doi.org/10.1016/j.jbvi.2019.e00119.

Solomon A et al. 2011. Don't lock me out: Lifestory interviews of family business 
owners facing succession. Family Process 50(2):149-166.https://doi.org/10.1111/j.15455300.2011.01352.x.

Stavrou ET. 1999. Succession in family businesses: Exploring the effects of demographic factors on offspring intentions to join and take over the business. Journal of Small Business Management 37(3):43-61.

Strauss AL, Corbin JM. 1990. Basics of Qualitative Research: Grounded Theory Procedures and Techniques. New York: SAGE Publications.

Tirdasari NL, Dhewanto W. 2012. Family business succession in Indonesia: A study of hospitality industry. Procedia - Social and Behavioral Sciences $\quad$ 57:69-74.https://doi.org/10.1016/j. sbspro.2012.09.1159.

Vera CF, Dean MA. 2005. An examination of the challenges daughters face in family business succession. Family Business Review 18(4):321-345.https://doi.org/10.1111/j.17416248.2005.00051.x.

Walter J. 2009. Strategic succession planning in the family business: A guide for executives. Business $1(2)$.

Wang C. 2010. Daughter exclusion in family business succession: A review of the literature. Journal of Family and Economic Issues 31(4):475-484. https://doi.org/10.1007/s10834-010-9230-3.

Westhead P, Howorth C. 2006. Ownership and management issues associated with family firm performance and company objectives. Family Business Review 19(4):301-316.https://doi. org/10.1111/j.1741-6248.2006.00077.x.

Yan J, Sorensen R. 2006. The effect of Confucian values on succession in family business. Family Business Review 19(3):235-250.https://doi. org/10.1111/j.1741-6248.2006.00072.x. 